\title{
HUBUNGAN EDUKASI PEMBERIAN MAKAN BAYI DAN ANAK DALAM MENINGKATKAN PENGETAHUAN IBU DI WILAYAH KERJA UPTD PUSKESMAS KECAMATAN PONTIANAK UTARA
}

\section{RELATIONSHIP EDUCATION FOR THE FEEDING OF INFANTS AND CHILDREN IN IMPROVING THE KNOWLEDGE OF MOTHERSIN WORK AREAS THE HEALTH UNIT SUBDISTRICT NORTH OF PONTIANAK}

\author{
Utin Harmiyanti*, Maria Fudji Hastuti*, Winarianti* \\ *Program Studi Keperawatan, Fakultas Kedokteran, Universitas Tanjungpura, \\ Jl. Prof. Dr. H. Hadari Nawawi, Pontianak \\ Email: utinharmiyantii@gmail.com
}

\begin{abstract}
ABSTRAK
Latar belakang: Nutrisi merupakan hal penting dalam masa tumbuh kembang anak. Kurangnya paparan informasi pada orang tua memberikan makanan yang tidak sesuai umur yang membuat perubahan pola gizi pada anak. Perawat sebagai edukator berperan penting dalam memberikan informasi untuk meningkatkan pengetahuan Ibu mengenai pemberian makan bayi dan anak.

Tujuan: Penelitian ini bertujuan untuk mengetahui hubungan pemberian informasi tentang pemberian makan bayi dan anak dalam meningkatkan pengetahuan Ibu di Wilayah Kerja UPTD Puskesmas Kecamatan Pontianak Utara.

Metode: Jenis penelitian ini adalah pre eksperimen design dengan desain penelitian pre and post test without control. Jumlah sampel 29 orang. Teknik pengambilan sampel dalam penelitian menggunakan teknik Purposive sampling.

Hasil: setelah dianalisis dengan uji Wilcoxon menunjukkan nilai $p=(0,675) \geq 0,05$ yang berarti bahwa hubungan edukasi pemberian makan bayi dan anak tidak ada hubungan.

Kesimpulan: Tidak ada hubungan antara edukasi pemberian makan bayi dan anak dalam meningkatkan pengetahuan ibu.
\end{abstract}

Kata Kunci: Nutrisi, Pemberian Makan Bayi dan Anak, Pengetahuan.

\begin{abstract}
Background: Nutrition is important in times of growing flower child. The lack of exposure information on older people give food that does not fit the pattern of making changes age of nutrition in children. Nurses as edukator plays an important role in providing information to enhance the knowledge of the mother regarding the feeding of infants and children.

Purpose: This research aims to know the relationship of the giving of the information about the feeding of infants and children in improving the knowledge of mothers in work areas North of Pontianak Subdistrict health centers Unit.

Method: This type of research is experimental design pre design research with pre and post test without control. The number of samples of 29 people. Sampling techniques in the research of using the technique of Purposive sampling.

Research Findings: After analyzed by Wilcoxon test showed the value of $p=(0.675) \geq 0.05$ educational relationship which means that feeding of infants and children there is no relationship.

Conclusions: There is no relationship between education feeding of infants and children in improving their knowledge of the mother.
\end{abstract}

Keywords: Nutrition, feeding of infants and children, knowledge. 


\section{PENDAHULUAN}

Anak merupakan aset masa depan dunia yang harus dirawat dengan baik sejak dini. Membangun anak yang kuat harus menjadi perhatian utama masyarakat (Depkes RI, 2015). Pemenuhan gizi merupakan hak dasar anak. Salah satu upaya untuk meningkatkan kesehatan dan gizi anak sebagaimana diamanatkan oleh UndangUndang Dasar Tahun 1945 dan Perjanjian Internasional seperti Konvensi Hak Anak, yakni memberikan makanan yang terbaik bagi anak usia dibawah 2 tahun. Untuk mencapai hal tersebut, Strategi Nasional Peningkatan Pemberian ASI dan MP-ASI merekomendasikan pemberian makanan yang baik dan tepat bagi bayi dan anak 0-24 bulan adalah: (1) inisiasi menyusui dini segera setelah lahir minimal selama 1 jam; (2) pemberian ASI eksklusif sampai usia 6 bulan; (3) memberikan makanan pendamping ASI (MP-ASI) mulai usia 6 bulan; (4) meneruskan pemberian ASI sampai usia 2 tahun atau lebih (Kementerian Kesehatan RI, 2014).

Asupan nutrisi seperti ASI dan MPASI memegang peranan penting dalam optimalisasi tumbuh kembang pada anak. Keadekuatan asupan nutrisi pada anak dapat dinilai dengan keadaan status gizi yang ditandai dengan anak kurus, normal, dan gemuk (Sulistyoningsih, 2011).

UNICEF sebagai salah satu organisasi yang menjaga hak-hak anak turut berperan dalam permasalahan nutrisi anak dengan melakukan berbagai intervensi yang terkait dengan praktik-praktik pemberian makanan anak dan gizi ibu yang merupakan kunci untuk menangani gizi kurang pada anak-anak. Untuk menangani gizi kurang, intervensi gizi perlu ditingkatkan yang dinyatakan dengan bukti ilmiah. Intervensi ini merupakan paket Intervensi Gizi Efektif (IGE) yang memberikan sebuah rangkaian layanan sejak pra-kehamilan sampai usia dua tahun yang mencakup 1000 hari kehidupan. Adapun yang seharusnya dimasukkan dalam paket Intervensi Gizi Efektif salah satunya yaitu konseling bagi ibu anak-anak muda dan praktik pemberian makan bayi dan anak yang tepat (Unicef, 2012).

Peranan ibu sangat diperlukan untuk melakukan semua intervensi tersebut sehingga secara tidak langsung menuntut ibu harus memiliki pengetahuan yang baik tentang pemberian makan pada bayi dan anak (Maimonah, 2009). Pengetahuan ibu tentang kebutuhan gizi sangat penting sekali, hal ini disebabkan untuk menciptakan generasi yang mendatang yang lebih baik (Soediatama, 2008). Pengetahuan merupakan hasil tahu dari seseorang setelah melakukan penginderaan terhadap suatu objek. Melalui proses belajar, seorang akan menjadi tahu sehingga akan dapat merubah perilaku sebelumnya. Sama halnya dengan kurangnya pengetahuan tentang gizi terutama pada sang ibu, akan berdampak kurangnya kemampuan mengaplikasikan informasi khususnya tentang gizi yang nantinya akan berakibat pada status gizi sang balita (Notoatmodjo,2011). Hal ini sesuai dengan pernyataan Roedjito dalam Erna (2010), pengetahuan gizi ibu dan status gizi anak berbanding lurus. Semakin baik pengetahuannya semakin baik juga status gizinya.

Menurut Siwi 2015, ada beberapa hal yang mempengaruhi status gizi secara langsung maupun tidak langsung. Secara langsung adalah intake nutrisi dan penyakit infeksi. Selain itu secara tidak langsung, ada beberapa faktor lain, yaitu persediaan pangan yang cukup, pendidikan ibu, pengetahuan gizi dan kesehatan serta pelayanan kesehatan, tingkat pendapatan keluarga atau status sosial ekonomi.

Andriani Pahlevi (2012), menyatakan bahwa ada hubungan antara pengetahuan ibu dengan status gizi balita. Pengetahuan gizi yang dibawah rata - rata, dapat menyebabkan usaha untuk mengoptimalkan gizi menjadi terhambat. Maka dari itu, pemerintah mengadakan program - program melalui penyuluhan dan lain-lain guna membantu masyarakat dalam mengatasi masalah gizi mereka .Salah satu cara untuk mendapatkan informasi tentang gizi atau nutrisi anak yaitu melalui edukasi. 
Edukasi kesehatan adalah suatu usaha sadar dan secara terus menerus dilakukan yang bertujuan mengubah perilaku individu, kelompok masyarakat dari kehidupan tidak sehat menjadi sehat (Sugihartono, 2007). Nurmasyita (2015), sesudah intervensi pendidikan gizi terdapat perbedaan rerata pengetahuan gizi yang bermakna antara kelompok perlakuan dan kelompok kontrol, perubahan pada kelompok perlakuan lebih tinggi daripada kelompok kontrol. Dalam keperawatan, edukasi merupakan salah satu bentuk intervensi keperawatan mandiri untuk membantu klien baik individu, kelompok maupun masyarakat dalam mengatasi masalah kesehatannya melalui kegiatan pembelajaran yang didalamnya perawat berperan sebagai perawat pendidik (Suliha, 2008).

Indonesia sebagai salah satu negara yang sedang berkembang masih menghadapi masalah kekurangan gizi yang cukup besar. Berdasarkan data WHO 2010, 1,5 juta anak meninggal karena pemberian makanan yang tidak tepat dan $90 \%$ diantaranya terjadi di negara berkembang. Anak-anak mudah sekali terkena penyakit karena kekebalan tubuh yang dimiliki masih rendah atau imunitas yang dimiliki belum terbentuk sempurna terutama penyakit infeksi seperti diare (Meadow\&Simon, 2008).

Berkaitan dengan uraian latar belakang tersebut, maka peneliti merumuskan masalah yang dibahas dalam penelitian ini yaitu apakah ada hubungan edukasi pemberian makan bayi dan anak dalam meningkatkan pengetahuan ibu di wilayah kerja UPTD Puskesmas Kecamatan Pontianak Utara.

\section{METODE}

Dalam penelitian ini menggunakan jenis penelitian kuantitatif dengan menggunakan desain penelitian pre eksperimen design (non designs). Desain ini dikatakan sebagai pre-eksperimental design karena belum merupakan eksperimen sungguh-sungguh karena masih terdapat variabel luar yang ikut berpengaruh terhadap terbentuknya variabel dependen. Rancangan ini berguna untuk mendapat informasi awal terhadap pertanyaan yang ada dalam penelitian (Sugiyono, 2010). Penelitian ini menggunakan desain pre and post test without control, yaitu peneliti hanya melakukan intervensi pada suatu kelompok tanpa pembanding. Efektifitas edukasi nilai pretest dan postest. Penelitian ini dilakukan di Wilayah Kerja UPTD Puskesmas Kecamatan Pontianak Utara yang dilaksanakan selama 3 minggu pada tanggal 18 Desember 2017 - 06 Januari 2018.

Populasi penelitian ini adalah seluruh ibu yang memiliki anak yang berusia $0-2$ tahun. Pengambilan sampel pada penelitian ini menggunakan perhitungan rumus lemeshow yang berjumlah 24 orang responden dengan kriteria inklusi yaitu, semua ibu yang memiliki anak yang berusia $0-2$ tahun yang bertempat tinggal di daerah Kecamatan Pontianak Utara. Adapun kriteria ekslusi yaitu, ibu yang memiliki usia anak $\geq$ 2 tahun dan ibu yang telah menandatangani lembar informed consent.

Instrumen yang digunakan dalam penelitian ini berupa lembar persetujuan, lembar kuesinor dan leaflet. Prosuder pengumpulan data pada penelitian ini yaitu peneliti meminta ijin untuk melakukan penelitian pada responden, kemudian memperkenalkan diri serta menjelaskan maksud dan tujuan penelitian, selanjutnya membagikan kuesioner pada responden yang terdiri dari 15 pernyataan untuk mengetahui tingkat pengetahuan ibu terhadap pemberian makan bayi dan anak.

\section{HASIL}

Tabel 4.1 Distribusi frekuensi dan persen karakteristik responden berdasarkan umur ibu, umur anak, pendidikan, pekerjaan, pengalaman penerimaan informasi, dan etnis.

\begin{tabular}{lcc}
\hline \multicolumn{1}{c}{ Variabel } & $\begin{array}{c}\text { Frekuensi } \\
(\boldsymbol{f})\end{array}$ & $\begin{array}{c}\text { Persen } \\
(\boldsymbol{\%})\end{array}$ \\
\hline Umur ibu & & \\
23 thn -29 thn & 15 & 62,6 \\
30 thn -41 thn & 9 & 37,3 \\
\hline Umur anak & & \\
1 thn -1 thn 9 bln & 15 & 62,7 \\
9 bln -2 thn & 9 & 37,5 \\
\hline Pendidikan & & \\
Tidak sekolah & 7 & 29,2 \\
SD & 7 & 34,5 \\
SMP & 8 & 33,3
\end{tabular}




\begin{tabular}{lcc} 
SMA/SMK & 2 & 8,3 \\
\hline Pekerjaan & & \\
IRT & 21 & 87,5 \\
Swasta & 3 & 12,5 \\
\hline \multicolumn{2}{l}{ Pengalaman Penerimaan } & Informasi \\
Belum pernah & 15 & 62,5 \\
Sudah pernah & 9 & 37,5 \\
\hline Etnis & & \\
Melayu & 14 & 58.3 \\
Jawa & 3 & 12,5 \\
Dayak & 6 & 25,0 \\
Cina & 1 & 4,2 \\
\hline Sumber: Data Primer
\end{tabular}

Sumber: Data Primer (2018), telah diolah

Berdasarkan tabel 4.1 menunjukkan bahwa, data karakteristik responden digunakan oleh peneliti untuk mengetahui faktor-faktor yang bisa mempengaruhi tingkat pengetahuan ibu terhadap pemberian makan bayi dan anak. Hasil distribusi dan frekuensi dari masing-masing karakteristik responden yang telah di uraikan merupakan jumlah persentase dari setiap karakteristik responden berdasarkan hasil output dari program spss yang kemudian di analisis.

Tabel 4.2 Distribusi Hasil Uji Normalitas Data

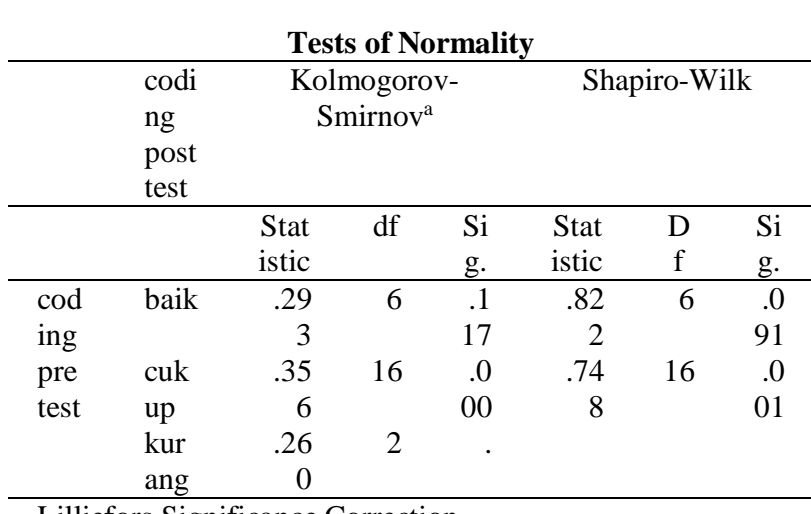

Lilliefors Significance Correction

Tabel 4.2 menjelaskan hasil uji normalitas data menggunakan uji ShapiroWilk karena total responden $\leq 50$. Dari hasil normalitas data didapatkan bahwa distribusi data tidak normal sehingga uji $\mathrm{T}$ berpasangan tidak dapat digunakan. Uji yang digunakan dalam penelitian ini adalah uji alternatif yaitu uji McNemar.

Tabel 4.3 Hasil Analisis Uji McNemar Hubungan Edukasi Pemberian Makan Bayi dan Anak Dalam Meningkatkan Pengetahuan Ibu Sebelum Dan Sesudah Edukasi

\begin{tabular}{lrrc}
\hline \multicolumn{4}{c}{ Chi-Square Tests } \\
& $\begin{array}{l}\text { Val } \\
\text { ue }\end{array}$ & Df & $\begin{array}{c}\text { Asymp. } \\
\text { Sig. (2- } \\
\text { sided) }\end{array}$ \\
\hline $\begin{array}{l}\text { McNemar- } \\
\text { Bowker Test }\end{array}$ & 1.53 & 3 & 0.675 \\
N of Valid & 3 & & \\
Cases & 24 & & \\
\hline
\end{tabular}

Sumber: Data Primer (2018), telah diolah

Berdasarkan hasil analisis tabel diatas, didapatkan dengan uji Mcnemar, diperoleh nilai significancy $0.675(\mathrm{p} \geq 0,05)$ dengan demikian disimpulkan "tidak ada hubungan pengetahuan yang bermakna antara sebelum edukasi dengan sesudah edukasi. Maka dapat disimpulkan bahwa hubungan edukasi pemberian makan bayi dan anak tidak ada hubungan dalam meningkatkan pengetahuan ibu di wilayah kerja UPTD Puskesmas Kecamatan Pontianak Utara.

\section{PEMBAHASAN}

Distribusi Frekuensi Dan Persentase Karakteristik Responden Berdasarkan Umur

Berdasarkan hasil penelitian yang dilakukan di Di Wilayah Kerja UPTD Puskesmas Kecamatan Pontianak Utara didapatkan bahwa distribusi frekuensi umur, dimana rentang umur 23-29 tahun lebih banyak dibandingkan rentang umur yang lainnya. Rentang usia 26-35 tahun dapat dikategorikan sebagai dewasa awal (Depkes, 2009). Usia seseorang juga mempengaruhi terhadap daya tangkap dan pola pikir seseorang. Semakin bertambah usia akan semakin berkembang pula daya tangkap dan pola pikirnya, sehingga pengetahuan yang diperolehnya semakin baik. Pada usia 20-35 tahun, individu akan lebih berperan aktif dalam masyarakat dan kehidupan sosial serta lebih banyak melakukan persiapan demi suksesnya upaya menyesuaikan diri menuju usia tua. Selain itu, mereka akan lebih banyak menggunakan banyak waktu untuk membaca. Kemampuan intelektual, pemecahan masalah dan kemampuan verbal dilaporkan hampir tidak ada penurunan pada usia ini (Erdian, 2009). Menurut Ochs 
\& Castaldi (2005) dalam Utari, Novayelinda \& Arneliwati (2011) pada tahan ini berdasarkan perkembangan psikologisnya merupakan masa dimana seseorang sudah memulai membina rumah tangga dan menjadi orang tua. Beberapa penelitian juga menjelaskan bahwa usia seseorang pada masa produktif memiliki tingkat pengetahuan atau kognitif yang paling baik. Selain itu, pada usia tersebut juga seseorang memiliki pengalaman dan kemampuan yang luas untuk beraktifitas yang tentunya akan menunjang pengetahuannya dalam segala hal (Pedro, 2015). Hasil ini didukung oleh pendapat Notoatmodjo (2007), usia seseorang mempengaruhi kemampuan seseorang untuk menerima informasi dan pola pikir seseorang terhadap informasi yang diberikan. Semakin bertambahnya usia maka kemampuan menerima informasi dan pola pikir seseorang semakin berkembang. Kemampuan seseorang untuk menerima informasi yang diberikan kepadanya berhubungan dengan fungsi tubuh baik indera maupun otak dan kesehatan seseorang.

Menurut teori Human Development dari Havighurst (1953) dalam Mulyapradana (2012) menyebutkan delapan tugas perkembangan pada masa dewasa awal atau dewasa muda salah satunya yaitu memulai jenjang karier namun disisi lain bertanggung jawab sebagi orang tua bagi anak dan menjadi andalan bagi pasangannya. Peran dan fungsi orangtua terutama ibu sangat penting karena seorang ibu harus menjamin ketahanan kesehatan anggota keluarganya.

\section{Distribusi Frekuensi Dan Persentase Karakteristik Responden Berdasarkan Pendidikan}

Berdasarkan hasil penelitian yang dilakukan di Di Wilayah Kerja UPTD Puskesmas Kecamatan Pontianak Utara didapatkan bahwa distribusi frekuensi pendidikan dasar lebih tinggi bahkan mendominasi dibandingkan dari yang tidak sekolah, hal ini menandakan bahwa pendidikan masih dianggap penting bagi responden walaupun mayoritas responden dikategorikan dalam pendidikan rendah, adapun faktor lain mengapa responden pendidikannya masih rendah karena kondisi ekonomi yang tidak memadai sehingga sekolah sampai jenjang Sma dirasa sudah cukup. Adanya hubungan antara tingkat pendidikan dengan tingkat pengetahuan tidak dapat dipungkiri bahwa makin tinggi pendidikan seseorang semakin tinggi pula mereka menerima informasi dan pada akhirnya semakin banyak pula pengetahuan yang dimilikinya. Sebaliknya jika seseorang tingkat pendidikannya rendah, maka akan menghambat perkembangan sikap seseorang terhadap penerimaan informasi dan nilainilai yang baru diperkenalkan. Hasil penelitian yang dilakukan oleh Purwati (2013) bahwa tingkat pengetahuan yang dipengaruhi oleh pendidikan, untuk tingkat pendidikan lebih tinggi maka tingkat pengetahuannya juga lebih baik. Pendidikan adalah proses pengubahan sikap dan tata laku seseorang atau kelompok dan juga usaha mendewasakan seseorang melalui upaya pengajaran dan pelatihan baik di sekolah ataupun di luar sekolah. Makin tinggi pendidikan, makin mudah seseorang menerima pengetahuan. Tingkat pendidikan juga mempengaruhi persepsi seseorang untuk lebih menerima ide-ide dan teknologi baru. Pendidikan juga merupakan salah satu faktor yang mempengaruhi persepsi seseorang. Karena dapat membuat seseorang untuk lebih mudah mengambil keputusan dan bertindak (Irmayanti, 2007). Menurut Mubarak (2011), makin tinggi pendidikan seseorang semakin mudah pula mereka menerima informasi, dan pada akhirnya semakin banyak pula pengetahuan yang dimilikinya, sebaliknya jika seseorang tingkat pendidikannya rendah akan menghambat perkembangan seseorang terhadap penerimaan informasi, dan nilainilai yang baru diperkenalkannya. Menurut Y.B Mantra yang dikutip oleh notoatmodjo (2003), pendidikan dapat mempengaruhi seseorang termasuk perilaku seseorang akan pola hidup terutama dalam motivasi untuk sikap, berperan dalam pembangunan kesehatan. Makin tinggi pendidikan 
seseorang makin mudah menerima informasi, sehingga makin banyak pula pengetahuan yang dimiliki. Sebaliknya, semakin rendah atau kurang pendidikan akan menghambat perkembangan sikap seseorang terhadap nilai-nilai yang baru diperkenalkan.

\section{Distribusi Frekuensi Dan Persentase Karakteristik Responden Berdasarkan Pekerjaan}

Berdasarkan hasil penelitian yang dilakukan di Di Wilayah Kerja UPTD Puskesmas Kecamatan Pontianak Utara Tahun di dapatkan bahwa distribusi frekuensi pekerjaan IRT lebih tinggi, penjelasan lain yang mendukung adalah kemampuan otak atau kognitif seseorang akan bertambah ketika sering digunakan untuk beraktifitas dan mengerjakan sesuatu dalam bentuk teka-teki atau penalaran. Pekerjaan sangat menentukan terhadap seseorang untuk berbuat suatu kegiatan. Pekerjaan yang dimaksud adalah pekerjaan ibu, dengan banyak kesibukan maka ibu kadang-kadang lupa untuk memberi makanan yang sehat kepada bayi atau anaknya, namun pekerjaan bukan penghambat dalam bertindak bila ada kemauan ataupun ibu memiliki pengetahuan yang baik terhadap kesehatan. Mayoritas pekerjaan responden adalah dalam penelitian ini yaitu ibu rumah tangga. Peneliti lebih banyak bertemu dengan istri dari pada suami karena istri sering berada di rumah dan bekerja sebagai ibu rumah tangga. Istri dipandang sebagai pengurus rumah tangga dan berperan sebagai perawat anak, pemimpin kesehatan keluarga, sahabat atau teman bermain anak (Friedman, Bowden \& Jones,2010). Ibu rumah tangga berperan untuk mengurus rumah tangga, sebagai pengasuh dan pendidik anak-anaknya, pelindung dan salah satu kelompok sosial serta sebagai anggota masyarakat dan lingkungan (Efendi, 2009). Namun ibu rumah tangga masih harus mempunyai tanggung jawab untuk mencari informasi baru yang dapat menunjang kesehatan keluarga salah satunya yaitu informasi kesehatan. Informasi kesehatan ini dapat diperoleh melalui interaksi, melihat media elektronik atau mengikuti media penyuluhan Peran pengasuh anak inilah yang menuntut ibu terus memperhatikan dan mengikuti perkembangan perilaku kesehatan yang benar dengan mengikuti kegiatan edukasi kesehatan.

\section{Distribusi Frekuensi Dan Persentase Karakteristik Responden Berdasarkan Etnis}

Berdasarkan hasil penelitian yang dilakukan di Di Wilayah Kerja UPTD Puskesmas Kecamatan Pontianak Utara didapatkan bahwa distribusi frekuensi etnis terbesar adalah suku melayu. Hal ini tidak terlepas karena moyoritas masyarakat di Wilayah Kerja UPTD Puskesmas Kecamatan Pontianak Utara beragama islam sehingga etnis melayu lebih dominan dibandingkan etnis yang lainnya. Adapun anggapan ibu menyatakan anak harus selalu patuh kepada orang tua sejak ia lahir sampai pada anaknya menikah sekalipun, hasil penelitian juga didapatkan bahwa ada beberapa ibu memberi makanan pendamping ASI sebelum bayi berumur 6 bulan dan didapatkan bahwa masih terdapat pantangan yang terjadi di kalangan masyarakat yang tidak memperbolehkan makan makanan tertentu. Menurut (Nur 2011) menyatakan bahwa dapat dikatakan persoalan pantangan atau tabu dalam mengkonsumsi makanan tertentu terdapat secara universal di seluruh dunia. Pantangan atau tabu adalah suatu larangan untuk mengkonsumsi jenis makanan tertentu, karena terdapat ancaman bahaya terhadap barang siapa yang melanggarnya. Dalam ancaman bahaya ini terdapat kesan magis, yaitu daya kekuatan superpower yang berbau mistik yang akan menghukum orangorang yang melanggar pantangan atau tabu tersebut. Tampaknya berbagai pantangan atau tabu pada mulanya dimaksudkan untuk melindungi kesehatan anak-anak dan ibunya, tetapi tujuan ini bahkan ada yang berakibat sebaliknya, yaitu merugikan kondisi gizi dan kesehatan. Di beberapa negara berkembang umumnya ditemukan larangan atau pantangan tertentu bagi wanita hamil di Indonesia wanita hamil dan setelah 
melahirkan dilarang makan telur, daging, udang, ikan laut dan lele, keong, daun lembayung, buah pare, nanas, gula merah, dan makanan yang digoreng dengan minyak (Afiyah Sri Harnany, 2006: 45). Reddy, P.H dalam Nur (2011) Peran orang tua terutama ibu dalam pengasuhan anak bawah lima tahun sangat besar. Balita belum mampu mengatur pola makannya sendiri, sehingga peran ibu sangat penting disini. Namun, keterbatasan pengetahuan ibu dan adanya pengaruh budaya setempat menjadi kendala dalam pengasuhan anak. Dalam setiap masyarakat ada aturan-aturan yang menentukan kuantitas, kualitas dan jenisjenis makanan yang seharusnya dan tidak seharusnya dikonsumsi oleh anggotaanggota suatu rumah tangga, sesuai dengan kedudukan, usia, jenis kelamin dan situasisituasi tertentu. Misalnya, ibu yang sedang hamil tidak diperbolehkan atau dianjurkan untuk mengkonsumsi makanan tertentu, ayah yang bekerja sebagai pencari nafkah berhak mendapat jumlah makanan yang lebih banyak dan bagian yang lebih baik daripada anggota keluarga yang lain, atau anak laki-laki diberi makan lebih dulu daripada anak perempuan. Walaupun pola makan ini sudah menjadi tradisi ataupun kebiasaan, namun seharusnya yang paling berperan mengatur menu setiap hari dan mendistribusikan makanan kepada keluarga adalah ibu, dengan kata lain ibu mempunyai peran sebagai gate-keeper dari keluarga.

Hubungan Edukasi Pemberian Makan Bayi Dan Anak Dalam Meningkatkan Pengetahuan Ibu Di Wilayah Kerja UPTD Puskesmas Kecamatan Pontianak Utara

Berdasarkan penelitian yang dilakukan di Wilayah Kerja UPTD Puskesmas Kecamatan Pontianak Utara didapatkan bahwa Pemberian Makan Bayi Dan Anak tidak ada hubungan dalam meningkatkan pengetahuan ibu dengan nilai $\mathrm{P}$ menunjukan 0,675 yang artinya tidak ada peningkatan pengetahuan terhadap hasil pengukuran pretes dan postes. Berdasarkan hasil penelitian dapat disimpulkan bahwa pemberian intervensi berupa edukasi tidak ada berpengaruh terhadap tingkat pengetahuan ibu, oleh karena itu peneliti berpendapat bahwa edukasi yang dilakukan secara berkala akan lebih efektif dalam meningkatkan pengetahuan seseorang, namun dibutuhkan juga persiapan yang matang dan memperhatikan faktor-faktor yang dapat mempengaruhi keberhasilan proses edukasi. Menurut pendapat peneliti untuk lebih meningkatkan pengetahuan ibu terhadap Pemberian Makan Bayi Dan Anak sangat diharapkan sekali pembinaan dan penyuluhan dari instansi terkait baik dari dinas kesehatan, tenaga kesehatan, kader, dan lembaga pemberdayaan masyarakat lainnya agar pengetahuan masyarakat meningkat dan terjadinya perubahan perilaku untuk menerapkan pemberian makan bayi dan anak yang tepat sehingga menunjang perilaku hidup sehat dan kesejahteraan kesehatan.

Adapun terkait yaitu penelitian Helmi tahun (2016) sejalan dengan penelitian yang dilakukan peneliti saat ini. Pada penelitian Helmi 2016 dimana ada pengaruh pendidikan kesehatan terhadap tingkat pengetahuan dan sikap tentang imunisasi. Menurut Fitriani (2011) mendefenisikan edukasi kesehatan sebagai suatu pengalaman yang dapat menimbulkan suatu pemahaman baru serta mempengaruhi kebiasaan, sikap dan pengetahuan seseorang atau masyarakat. Hal ini membuktikan bahwa seseorang atau masyarakat yang sudah terpapar pendidikan kesehatan atau mendapat informasi terkait baik dari petugas kesehatan maupun orang lain dapat mempengaruhi pengetahuan, sikap dan kebiasaan seseorang. Maka dari itu edukasi kesehatan penting dilakukan dengan memperhatikan faktor-faktor yang dapat mempengaruhi pengetahuan seseorang. Pengetahuan dapat dibagi menjadi enam tingkatan, diantaranya adalah tahu (know), memahami (comprehension), aplikasi (application), analisis (analysis), sintesis (synthesis), dan evaluasi (evalution) (Notoatmodjo, 2007). Tingkat pengetahuan seseorang sangat berpengaruh terhadap perilaku karena semakin baik tingkat pengetahuan yang dimiliki, maka semakin baik pula perilaku yang dilakukan. Hal 
tersebut karena pengetahuan seseorang tentang suatu hal akan mempengaruhi sikapnya. Sikap positif maupun negative tergantung dari pemahaman individu tentang suatu hal tersebut, sehingga sikap ini selanjutnya akan mendorong individu melakukan perilaku tententu pada saat dibutuhkan, tetapi jika sikap yang dilakukan negative, maka seseorang tersebut akan menghindari untuk melakukan perilaku tersebut (Paramita, 2010). Efendy (2009) mengatakan sebagian besar pengetahuan manusia diperoleh melalui mata dan telinga seperti poster, buklet, leaflet, slide atau informasi yang berupa tulisan dan informasi yang berbentuk suara seperti ceramah, penyuluhan atau video yang membantu menstimulasi penginderaan dalam proses pembelajaran.

\section{SIMPULAN DAN SARAN}

\section{Simpulan}

Berdasarkan hasil penelitian yang dilakukan di Di Wilayah Kerja UPTD Puskesmas Kecamatan Pontianak Utara di dapatkan bahwa distribusi frekuensi umur, didapatkan distribusi frekuensi rentang umur tinggi yaitu umur ibu 23-29 tahun $(62,6 \%)$ dan rentang umur anak 1 tahun-1 tahun 9 bulan $(62,7 \%)$. Berdasarkan hasil penelitian yang dilakukan di Di Wilayah Kerja UPTD Puskesmas Kecamatan Pontianak Utara di dapatkan bahwa distribusi frekuensi pendidikan dasar lebih tinggi bahkan mendominasi dibandingkan dari yang tidak sekolah, hal ini menandakan bahwa pendidikan masih dianggap penting bagi responden walaupun mayoritas responden dikategorikan dalam pendidikan rendah, adapun faktor lain menggapa responden pendidikannya masih rendah karena kondisi ekonomi yang tidak memadai sehingga sekolah sampai jenjang sma dirasa sudah cukup. Berdasarkan hasil penelitian yang dilakukan di Di Wilayah Kerja UPTD Puskesmas Kecamatan Pontianak Utara di dapatkan bahwa distribusi frekuensi pekerjaan IRT lebih tinggi, penjelasan lain yang mendukung adalah kemampuan otak atau kognitif seseorang akan bertambah ketika sering digunakan untuk beraktifitas dan mengerjakan sesuatu dalam bentuk tekateki atau penalaran. Pekerjaan sangat menentukan terhadap seseorang untuk berbuat suatu kegiatan. Pekerjaan yang dimaksud adalah pekerjaan ibu, dengan banyak kesibukan maka ibu kadang-kadang lupa untuk memberi makanan yang sehat kepada bayi atau anaknya, namun pekerjaan bukan penghambat dalam bertindak bila ada kemauan ataupun ibu memiliki pengetahuan yang baik terhadap kesehatan. Berdasarkan hasil penelitian yang dilakukan di Di Wilayah Kerja UPTD Puskesmas Kecamatan Pontianak Utara didapatkan bahwa distribusi frekuensi etnis terbesar adalah suku melayu. Hal ini tidak terlepas karena moyoritas masyarakat di Wilayah Kerja UPTD Puskesmas Kecamatan Pontianak Utara beragama islam sehingga etnis melayu lebih dominan dibandingkan etnis yang lainnya. Berdasarkan penelitian yang dilakukan di Wilayah Kerja UPTD Puskesmas Kecamatan Pontianak Utara didapatkan bahwa Pemberian Makan Bayi Dan Anak efektif dalam meningkatkan pengetahuan ibu dengan nilai $\mathrm{P}$ menunjukan 0,675 yang artinya tidak ada hubungan pengetahuan terhadap hasil pengukuran pretes dan postes.

\section{Saran}

Bagi institusi pelayanan kesehatan yaitu memberi informasi bagi tenaga kesehatan dalam meningkatkan pengetahuan ibu terhadap edukasi pemberian makan pada bayi dan anak dalam kegiatan promosi kesehatan untuk meningkatkan perilaku hidup sehat, bagi orang tua yaitu Peneliti berharap responden menerima informasi tentang edukasi pemberian makan bayi dan anak sehingga dapat meningkatkan pengetahuan ibu dan menerapkan dalam kehidupannya sehari-hari, dan bagi penelitian selanjutnya diharapkan menggunakan metode yang berbeda dan menggunakan kelompok pembanding untuk mengetahui efektifitas pemberian makan bayi dan anak dalam meningkatkan pengetahuan ibu. 


\section{DAFTAR PUSTAKA}

1. (PERSAGI), P. A. (2009). Kamus Gizi. Jakarta: Kompas.

2. 1195/Menkes/SK/XII/2010, K. M. (2010). Tentang Standar Antropomentri Penilaian Status Gizi Anak. Jakarta: Kemenkes RI.

3. A.Aziz, H. (2008). Pengantar Ilmu Keperawatan Anak 1. 2008: Salemba Medika.

4. Almatsier, S. (2009). Prinsip Dasar Ilmu Gizi. Jakarta: Rineka Cipta.

5. Adriani, P. (2012). Peranan Gizi dalam Siklus Kehidupan. Jakarta: Prenada Media Group.

6. Arikunto, S. (2003). Prosedur Penelitian. Jakarta: PT. Asdi Maha Satya.

7. Bumi, C. (2009). Pengaruh Ibu yang Bekerja terhadap Status Gizi Balita di Kelurahan Mangunjiwan Kabupaten Demak.

Demak: http://skripsistikes.wordpress.com/2009/0 5/03/ikpiii.com.

8. Dharma, K.K. 2011. Metodologi Penelitian Keperawatan Panduan Melaksanakan dan Menerapkan Hasil Penelitian. Jakarta : Trans Info Medika

9. Dahlan, S. (2013). Statistik untuk Kedokteran dan Kesehatan Edisi 5. Jakarta: Salemba Medika.

10. Depkes, RI. (2010). Buku Bagan Manajemen Terpadu Balita Sakit (MTBS). Jakarta: Depkes.

11. Depkes, RI. (2015). Laporan Nasional Riset Kesehatan Dasar. Jakarta.

12. Efendi, F. (2009). Keperawatan kesehatan komunitas. Jakarta: Salemba Medika.

13. Fitriani, S. (2011). Promosi Kesehatan. Yogyakarta: Graha Ilmu.

14. H, R. (2010). Statistik untuk Penelitian Kesehatan dengan Aplikasi Program $R$ dan SPSS. Yogyakarta: Pustaka Rihana.

15. Hidayat, A. (2009). Pengantar Ilmu Kesehatan Anak. 2009: Salemba Medika.

16. Machfoedz, I. (2013). Metodologi Penelitian (Kuantitatif dan Kualitatif) : Bidang Kesehatan, Keperawatan, Kebidanan, Kedokteran. Jakarta: Erlangga.
17. Notoatmodjo, S. (2011). Pendidikan dan Perilaku Kesehatan. Jakarta: Rineka Cipta.

18. Notoatmodjo, S. (2012). Metodologi Penelitian Kesehatan. Jakarta: Rineka Cipta.

19. Nursalam. (2003). Konsep dan Penerapan Metodologi Penelitian Ilmu Keperawatan. Jakarta: Salemba Medika.

20. Qurnia, A. T. (2009). Pengaruh Pengetahuan Ibu terhadap Kebutuhan Gizi Balita di Desa Bacong Kecamatan Wonoasri Kabupaten Madiun. Madiun: http:/srikpstikes.wordpress.com/2009/05/ 03/ikpiii/65.

21. RI, Depkes. (2012). Kajian Riset Operaional Intensifikasi Pemberantasan Penyakit Menular Tahun 2010. Jakarta: Depkes.

22. Riwidikdo. (2010). Statistik untuk Penelitian Kesehatan dengan Aplkasi $R$ dan SPSS. Yogyakarta: Pustaka Rihana.

23. Siregar, M. (2008). Pengaruh Pengetahuan Ibu terhadap Kurang Kalori Protein pada Anak. http://referensiaasyariabdullah.blogspot.c om/2008/04.

24. Soegeng, S. (2004). Kesehatan dan Gizi. Jakarta: PT. Asdi Mahasatya.

25. Sugiyono. (2013). Metode Penelitian Kuantitatif, Kualitatif dan $R \quad \& \quad D$. Bandung: Alfabeta.

26. Simon, R. M. (2008). Lecture Notes Pediatrika Edisi 7. Jakarta: Erlangga.

27. World Health Organization.(2012). Child Growth Standart and the Identfication of Severe Acute Malnutriotion in Infants and Children.

28. Wong, D.L. (2002). Buku Ajar Keperawatan Pediatrik Volume 1. Edisi 6.Jakarta : Buku Kedokteran EGC

29. Wong, D. L. (2003). Pedoman Klinis Keperawatan Pediatrik Edisi 4. Jakarta: Buku Kedokteran EGC.

30. Wong, D. L. (2009). Buku Ajar Keperawatan Pediatrik Edisi 6. Jakarta: Buku Kedokteran EGC

31. Zuldafrial. (2012). Penelitian Kuantitatif. Yogyakarta: Media Prakarsa 